\title{
Abbreviations, dates, and quotations
}

\section{ABBREVIATIONS}

Add. Additional Manuscript

All Souls Codrington Library, All Souls College, Oxford

BL British Library, London

Bod. Bodleian Library, Oxford

Christ Church Christ Church Library, Oxford CUL Cambridge University Library, Cambridge

KSRL Kenneth Spencer Research Library, University of Kansas, Lawrence, Kansas

LPL Lambeth Palace Library, London

Portland Manuscripts of his Grace the Duke of Portland, K. G., Preserved at Welbeck Abbey, 8 vols. London: Ben Johnson $\&$ Co., I907.

RS Royal Society of London

TNA The National Archives, London

\section{DATES}

All dates are given with the assumption that the year began on I January even though during the period of this study, England celebrated New Year's Day on 25 March.

\section{QUOTATIONS}

In this book the original spelling, underlining, and italics found in quotations from published and manuscript material are preserved. However, for the sake of clarity, some abbreviations have been silently expanded. All biblical references are taken from the King James Version. 
Jeffrey R. Wigelsworth - 9781847793560 Downloaded from manchesterhive.com at 04/26/2023 10:20:38AM via free access 